\title{
ICE-CORE ANALYSIS ON THE SIPLE COAST OF WEST ANTARCTICA
}

\author{
by
}

Richard B. Alley and Charles R. Bentley

(University of Wisconsin-Madison, Geophysical and Polar Research Center,

1215 W. Dayton Street, Madison, WI 53706-1692, U.S.A.)

\section{ABSTRACT}

Pit and core studies at the Upstream B camp (UpB) and ridge $\mathrm{BC}(\mathrm{BC})$ on the Siple Coast, West Antarctica, have revealed a number of interesting results. Both sites have $10 \mathrm{~m}$ temperatures near $-26.5^{\circ} \mathrm{C}$ and accumulation rates near $0.09 \mathrm{~m} \mathrm{a}^{-1}$ of ice. At both sites, the low densities of annual depth-hoar layers arise in the first year following snow deposition. Densification rates at $\mathrm{UpB}$ are accelerated compared to $\mathrm{BC}$ and to other sites, probably owing to stress enhancement of power-law-creep densification caused by the large longitudinal deviatoric stresses at UpB. The connectivity of firn, measured by the number of bonds per grain and by the fraction of total surface area per grain involved in bonds, correlates well with density and shows no significant dependence on grain-size. The longitudinal stresses at UpB cause the ice to develop a fabric of horizontally elongated bubbles and grains, interpenetrating grains, and strain shadows between about $30-70 \mathrm{~m}$. Ice at BC below about $95 \mathrm{~m}$ shows rapid grain growth and development of a bimodal grain-size distribution, but no preferred orientation of grains or pores. The temperaturedepth profile to $100 \mathrm{~m}$ at $\mathrm{BC}$ suggests a basal heat flux near 1.9 heat-flow units (HFU), typical of a region of active rifting. Surface-melt events occur about once every 50 years, and correlate well between $\mathrm{UpB}$ and $\mathrm{BC}$.

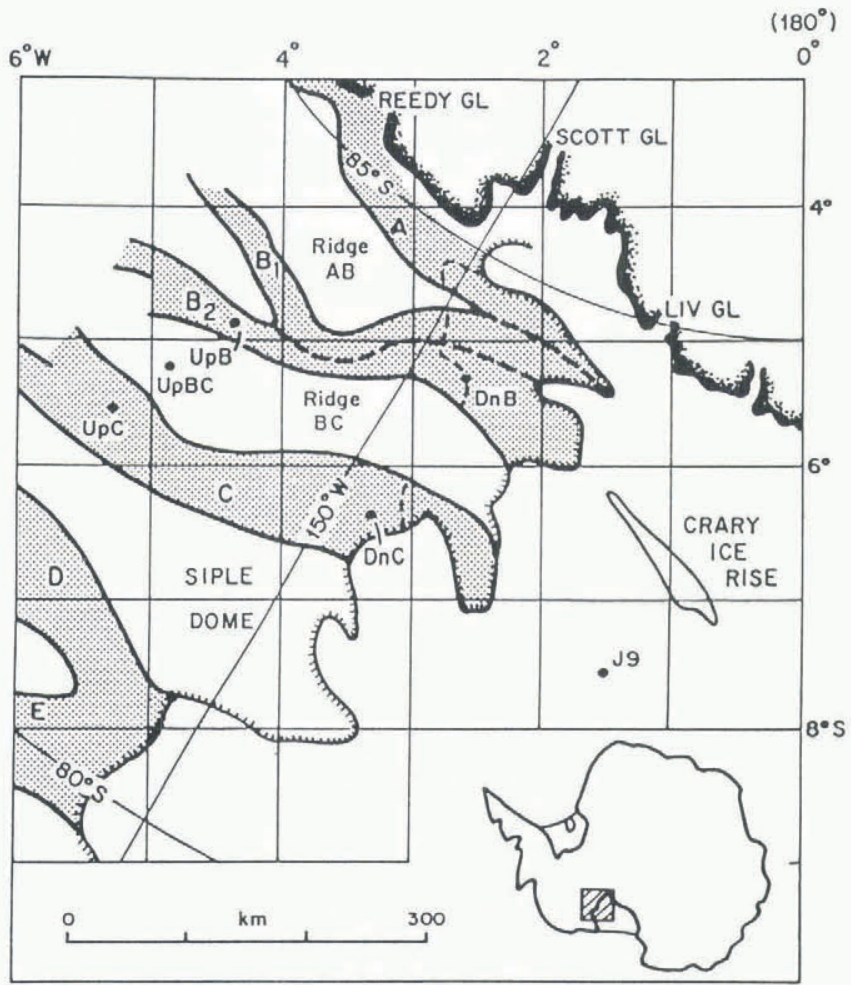

Fig. 1. Location map. $\mathrm{UpB}$ and $\mathrm{BC}$ (labeled $\mathrm{UpBC}$ ) are shown. Modified from Shabtaie and Bentley (1987).

\section{INTRODUCTION}

Here we present data from pits and from $100 \mathrm{~m}$ cores drilled by the Polar Ice Coring Office (PICO) on the Siple Coast of West Antarctica, at the Upstream B camp (UpB) (drilled 1984-85), and at the Ohio State University's North Camp on ridge BC (BC) (1985-86; Fig. 1, Table I). The UpB core melted partially during shipment, so only field data are available; the BC core was sampled more fully in the field and has been re-sampled in the laboratory. The methods used are described by Alley (unpublished).

\section{TABLE I. SITE CHARACTERISTICS}

\begin{tabular}{|c|c|c|}
\hline & UpB & $\mathrm{BC}$ \\
\hline Location $^{1}$ & $\begin{array}{c}83^{\circ} 28^{\prime} 40^{\prime \prime S} \\
138^{\circ} 05^{\prime} 49^{\prime \prime} \mathrm{W}\end{array}$ & $\begin{array}{r}82^{\circ} 53^{\prime} 31^{\prime \prime S} \\
136^{\circ} 39^{\prime} 37^{\prime \prime W}\end{array}$ \\
\hline Elevation $^{1}$ & $335 \mathrm{~m}$ & $509 \mathrm{~m}$ \\
\hline $10 \mathrm{~m}$ temperature $\mathrm{e}^{2}$ & $-26.4^{\circ} \mathrm{C}$ & $-26.5^{\circ} \mathrm{C}$ \\
\hline Ice accumulation & $0.086 \mathrm{~m} \mathrm{a}^{-1}$ & $0.090 \mathrm{~m} \mathrm{a}^{-1}$ \\
\hline
\end{tabular}

1 Locations and elevations from Whillans and others (1987).

2 Temperature at UpB (personal communication from S. Shabtaie, 1985).

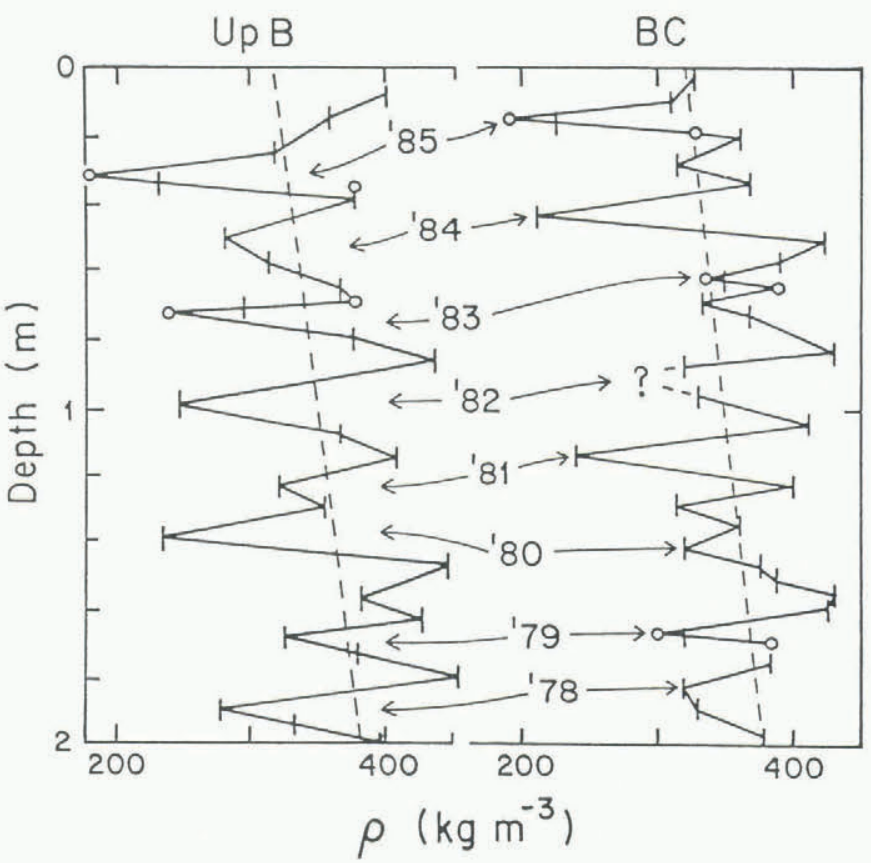

Fig. 2. Depth-density plot for pits at UpB and BC. Densities indicated by open circles were calculated from mass differences between adjacent samples including and excluding the layer in question. The depth-hoar layer from each autumn is indicated by its year of deposition: '79 stands for 1979 and ' 85 stands for 1985. No density was measured for the BC 1982 hoar layer, but it appeared to be similar to hoar layers above and below it. 


\section{PIT OBSERVATIONS}

Detailed pit studies show a well-developed annual cycle at UpB and $\mathrm{BC}$, marked by thick $(\approx 50 \mathrm{~mm})$, autumnal depth-hoar layers (Gow 1965; Alley, in press). This annual signal is also evident in depth-density profiles of the pits (Fig. 2), although grain-size data are required in order to remove slight ambiguities in the annual signal as seen in densities.

The densities shown in Figure 2 were measured with standard snow-density tubes $(\approx 57.5 \mathrm{~mm}$ inside diameter $)$, which had been inserted horizontally with regard to stratification. The average accumulation rates determined from the interpreted depth-density profiles (Table I) agree closely with rates calculated from identification of fall-out horizons from atmospheric testing of nuclear weapons (Whillans and Bindschadler 1988, this volume), which tends to verify the interpretation of Figure 2.

Densities of the autumnal depth-hoar layer and the densest (fine-grained) layer deposited during the previous year are listed in Table II for both sites. Table III shows

\section{TABLE II. DEPTH-DENSITY DATA FROM PITS}

\begin{tabular}{lcccccc} 
Year & \multicolumn{3}{c}{$\mathrm{UpB}$} & \multicolumn{3}{c}{$\mathrm{BC}$} \\
\hline & $\rho_{\mathrm{f}}$ & $\rho_{\mathrm{h}}$ & $\Delta$ & $\rho_{\mathrm{f}}$ & $\rho_{\mathrm{h}}$ & $\Delta$ \\
\hline 1985 & 376 & 177 & 199 & 368 & 189 & 179 \\
1984 & 375 & 280 & 95 & 425 & 210 & 215 \\
1983 & 435 & 238 & 197 & 430 & 334 & 96 \\
1982 & 408 & 245 & 163 & - & - & - \\
1981 & 354 & 321 & 33 & 400 & 239 & 161 \\
1980 & 447 & 284 & 163 & 432 & 319 & 113 \\
1979 & 453 & 326 & 127 & 384 & 298 & 86
\end{tabular}

$\rho_{\mathrm{h}}$ and $\rho_{\mathrm{f}}$ are densities of depth hoar from autumn of year (A.D.) indicated and of densest fine-grained firn in preceding year respectively, and $\Delta=\rho_{\mathrm{f}}-\rho_{\mathrm{h}}$. Densities are in $\mathrm{kg} \mathrm{m}^{-3}$.

TABLE III. DENSIFICATION RATES IN UPPER $2 \mathrm{M}$ ON SIPLE COAST

\begin{tabular}{lcc} 
Firn type & $\begin{array}{c}\text { Densification } \\
\text { rate } \\
\left(\mathrm{kg} \mathrm{m}^{-3} \mathrm{a}^{-1}\right)\end{array}$ & $\begin{array}{c}\text { Conf idence } \\
\text { level }\end{array}$ \\
\hline Hoar & $17.6 \pm 5.3$ & $>99 \%$ \\
Fine & $5.8 \pm 4.2$ & $80 \%$ \\
Hoar-fine & $11.8 \pm 6.6$ & $90 \%$ \\
\hline
\end{tabular}

"Confidence level" is the statistical likelihood that the densification rate exceeds zero.

the densification rates for these depth-hoar layers and finegrained layers, determined by least-squares regression of the combined data set for both sites, as well as the rate at which the density range changes. It is clear that the density of depth hoar increases rapidly with age, whereas that of fine-grained firn increases more slowly, causing the density range to decrease with increasing age. This indicates that any net mass loss from firn layers to the free atmosphere is significantly less than the densification rate for all types of firn and for all depths considered here $(\geqslant 0.2 \mathrm{~m})$, and that the low densities of depth-hoar layers originate in the top $0.2 \mathrm{~m}$ and thus in the first year following snow deposition (Alley, in press).

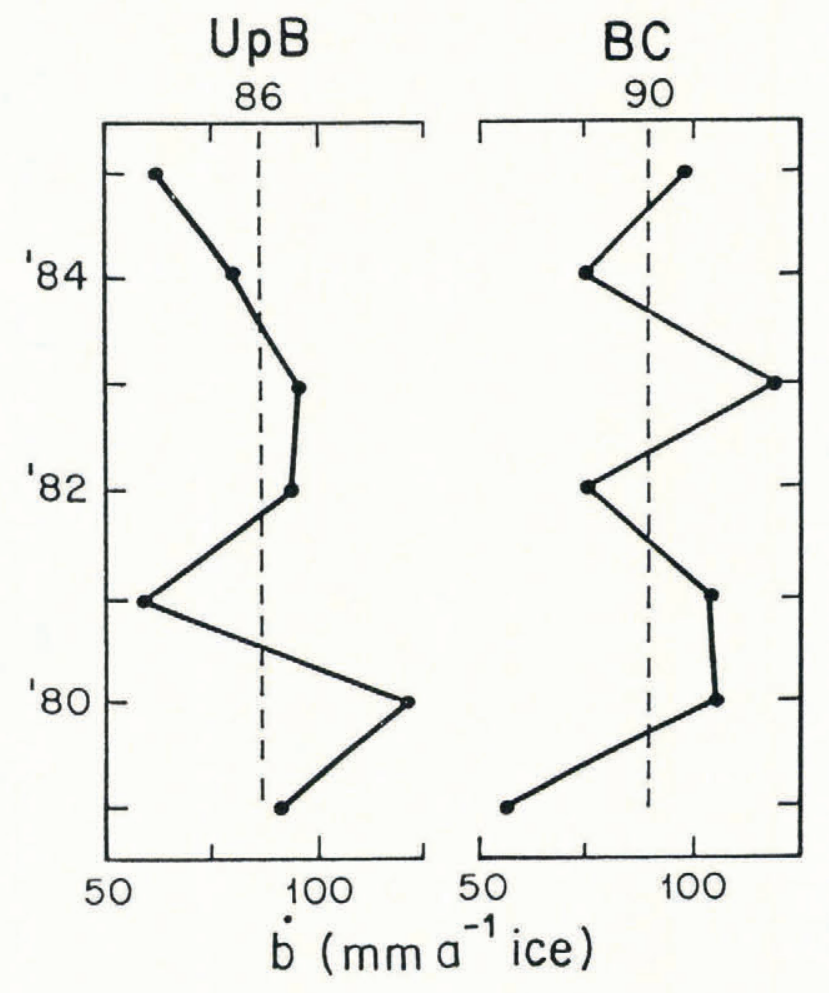

Fig. 3. Accumulation rates for $\mathrm{UpB}$ and $\mathrm{BC}$, calculated from Figure 2.

Annual accumulation amounts from Figure 2 are plotted in Figure 3. Considerable inter-annual variability is evident, with a standard deviation of about $22 \mathrm{~mm} \mathrm{a}^{-1}$ ice at both sites. For the accumulation rates at these sites, Giovinetto (1964) estimated total inter-annual variability of about $30 \mathrm{~mm} \mathrm{a}^{-1}$, which is in reasonably good agreement with the present figure.

\section{DEPTH-DENSITY PROFILES}

Depth-density data for the cores and pits are shown in Figures 4-6. Isostatic weighing (Gow 1968) was not available in the field at $\mathrm{UpB}$, so density measurements were terminated near the firn-ice transition, where errors in the volume-mass method became large compared to physical variations. Figure 6 shows the smoothed depth-density profiles drawn through the data by inspection. Figure 7 shows the densification rates calculated from Figure 6 and the stress on intergranular necks, which causes densification

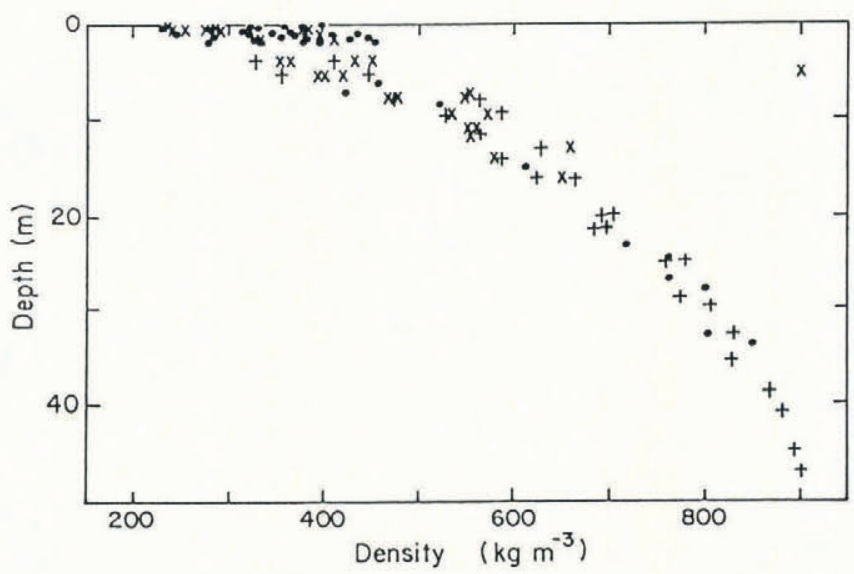

Fig. 4. Depth-density data from UpB. Symbols for Figures 4 and 5 are as follows: point-count densities are shown by $x$, volume-mass densities on samples $\leqslant 0.1 \mathrm{~m}$ long are shown by + , volume-mass densities on samples $>0.1 \mathrm{~m}$ long are shown by solid circles, and densities from isostatic weighing in isooctane (Gow 1968) are shown by triangles. 


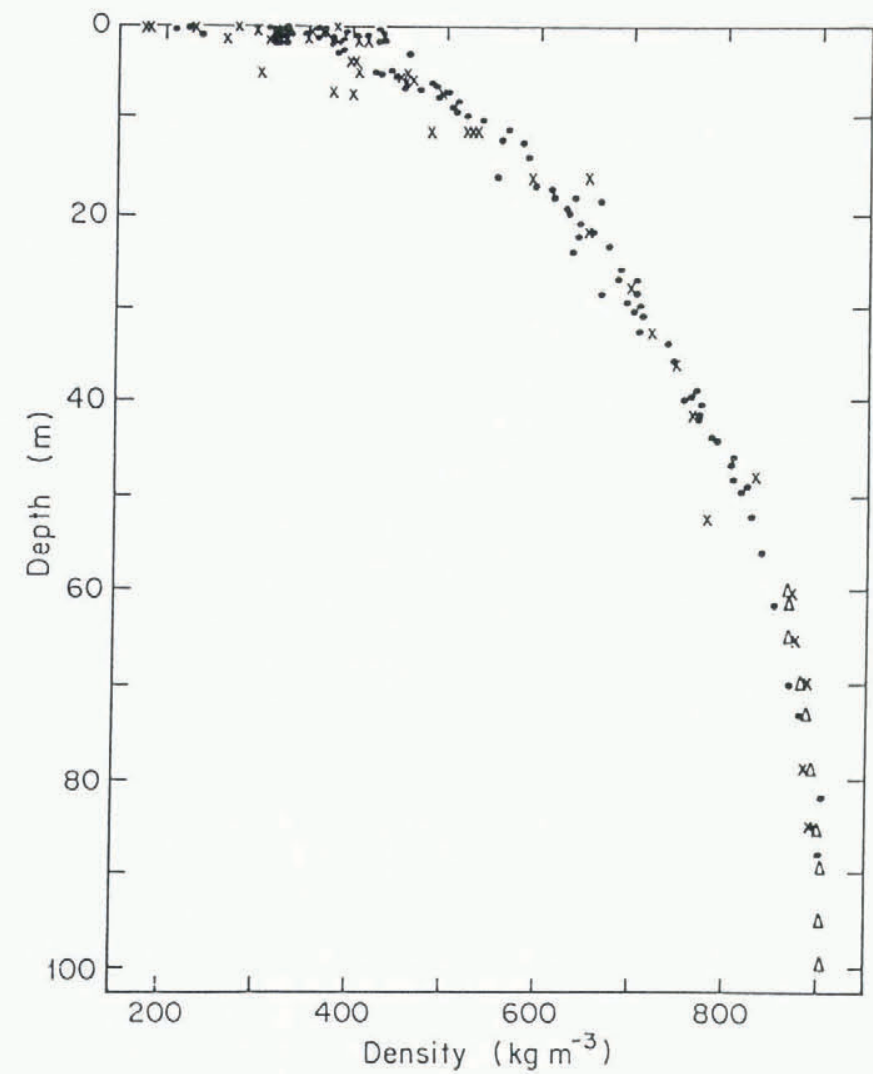

Fig. 5. Depth-density data from BC. Symbols are defined in the caption to Figure 4.

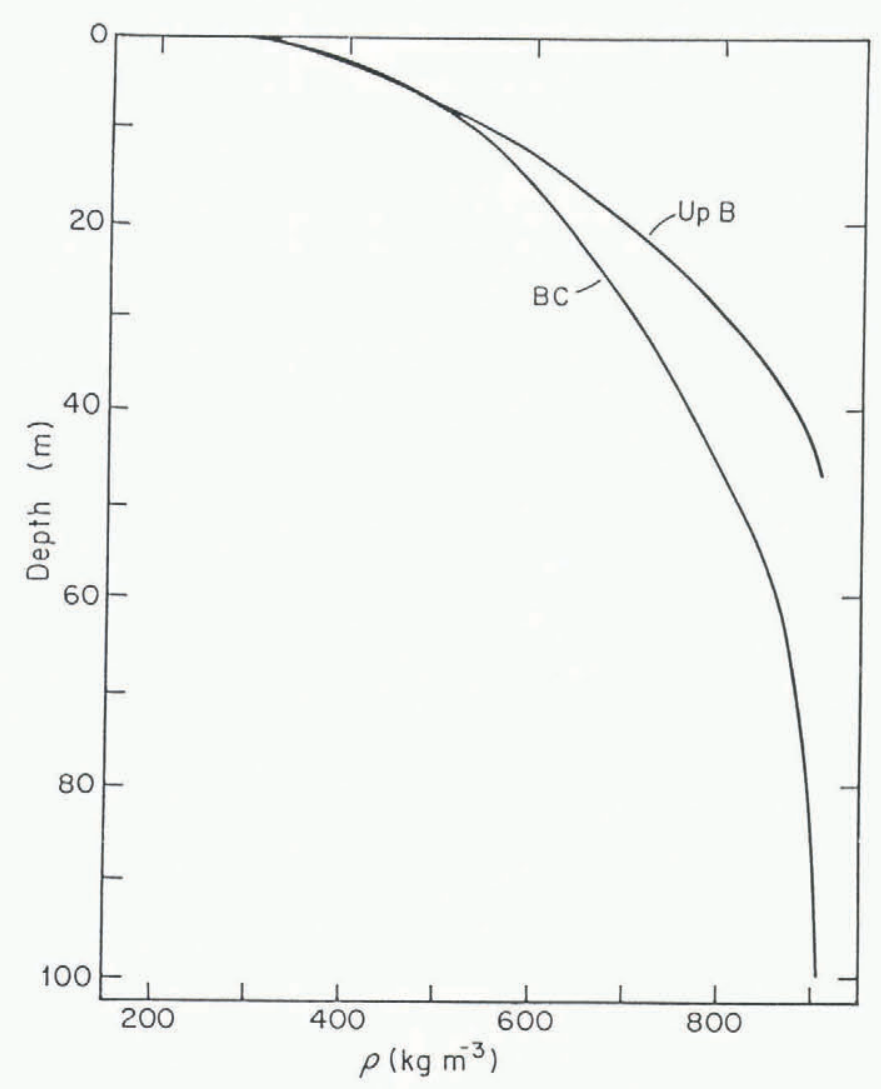

Fig. 6. Smoothed depth-density curves for UpB and BC.

(Alley and others 1982). Both here and below, ages were calculated from the depth-density profiles and the accumulation rates in Table $I$, which were assumed to be constant. Effects of vertical strain are small $(<1 \%$ at $40 \mathrm{~m})$ and similar for both cores, and have been ignored.

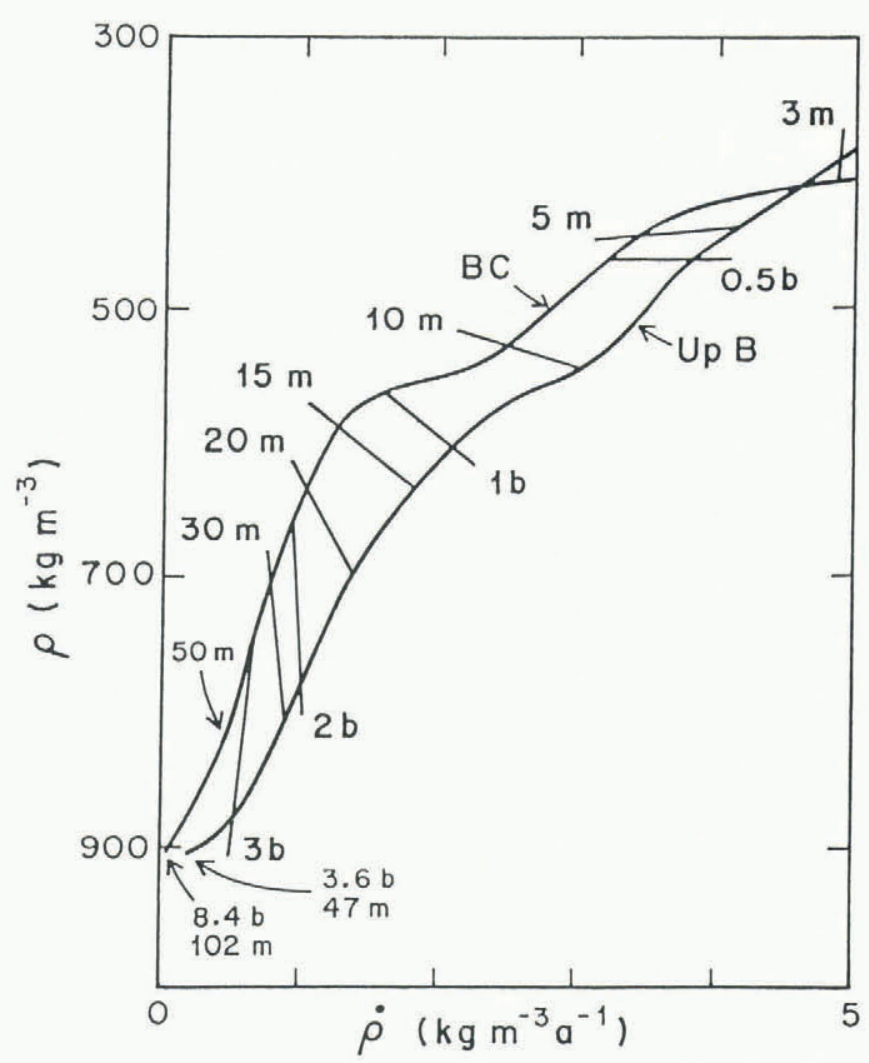

Fig. 7. Densification rate $(\dot{\rho})$ versus density $(\rho)$ for UpB and BC. Stresses from overburden pressure on intergranular necks in bars $(1$ bar $=100 \mathrm{kPa})$ and depths in meters are indicated.

At densities $>550 \mathrm{~kg} \mathrm{~m}^{-3} \mathrm{UpB}$ densifies significantly more rapidly than $\mathrm{BC}$; between 410 and $550 \mathrm{~kg} \mathrm{~m}^{-3} \mathrm{UpB}$ seems to densify more rapidly, but the difference falls within the scatter of data points and thus is not significant. Pore close-off $\left(830 \mathrm{~kg} \mathrm{~m}^{-3}\right)$ is reached at a depth of $33 \mathrm{~m}$ at UpB but not until $52 \mathrm{~m}$ at BC. From Gow (1975), the BC profile is normal for the temperature and accumulation rate there, but densification is anomalously rapid at UpB.

Rapid densification with depth is favored by high temperature and low accumulation. Regional gradients in temperature (Shimizu 1964, Robin 1983) and accumulation (Whillans and Bindschadler 1988, this volume) are zero or small for $100 \mathrm{~km}$ up-flow of UpB on the ice stream and farther into the catchment, and the temperature profiles at UpB (measured to $20 \mathrm{~m}$ depth; personal communication from S. Shabtaie, 1987) and BC (this study) are within $0.1^{\circ} \mathrm{C}$ of each other at 10 and $20 \mathrm{~m}$. Anomalously rapid densification is evident in firn that originated only $30 \mathrm{~km}$ from UpB; thus, changes in temperature and accumulation rate along the flow line cannot account for the rapid densification.

Zumberge and others (1960), Crary and Wilson (1961), and Gow (1968) presented evidence that large horizontal stresses cause accelerated firn densification. At UpB Vornberger and Whillans (1986) observed large longitudinal strain-rates and suggested that longitudinal deviatoric stresses exceed $200 \mathrm{kPa}$ in tension, with transverse compression almost as large. In ordinary, low-density firn, densification is dominated by linear-viscous grain-boundary sliding (Alley 1987a), which is independent of effective stress; however, at densities above about $550 \mathrm{~kg} \mathrm{~m}^{-3}$, power-law creep begins to dominate densification and increases with the square of the effective stress (Maeno and Ebinuma 1983). Rapid densification at $\mathrm{UpB}$ becomes evident in a region where neck stresses are about $100 \mathrm{kPa}$ (Fig. 7), where the density is about $550 \mathrm{~kg} \mathrm{~m}^{-3}$ and power-law creep should dominate. An additional longitudinal deviatoric stress of $200 \mathrm{kPa}$ acting across intergranular necks then would increase the rate of densification and would lower the density at which powerlaw creep becomes the dominant mechanism of densification. It thus seems likely that the rapid densification at UpB is the result of the softening effect of the large longitudinal deviatoric stresses in the ice stream. 


\section{STEREOLOGY}

Firn connectivity

Comparison of data from $\mathrm{UpB}$ and $\mathrm{BC}$ with data from Site A, Greenland $\left(-29.5^{\circ} \mathrm{C}, 0.29 \mathrm{~m} \mathrm{a}^{-1}\right.$ ice; Alley and Koci 1988), confirms earlier observations (e.g. Fuchs 1959) that density is a good estimator of firn connectivity. Here we measure connectivity in two ways: $\beta$, the average fraction of the total surface area of grains involved in bonds (i.e. ice-ice contact) as opposed to ice-air contact, and $n_{3}$, the average number of bonds per grain (co-ordination number; Alley 1987b). These quantities are plotted against density in Figures 8 and 9.

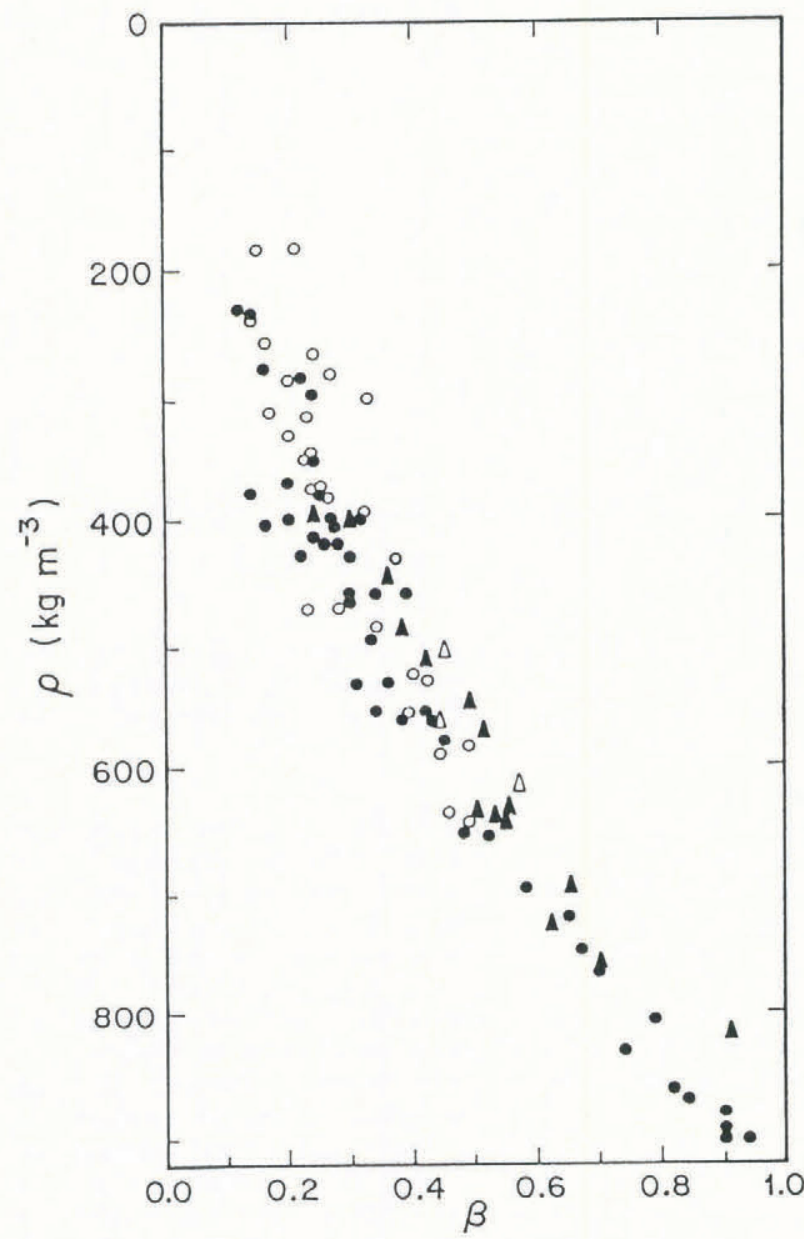

Fig. 8. Surface fraction of average grain involved in grain bonds $(\beta)$, plotted against density $(\rho)$. Circles represent data from UpB and $\mathrm{BC}$, triangles represent data from Site $A$, Greenland, solid symbols represent fine-grained and medium-grained firn, and open symbols represent coarse-grained firn and depth hoar.

Inspection of the figures shows no systematic difference between the Siple Coast and Site A, even though the temperatures, accumulation rates, and other factors are different. (A similar plot that distinguishes between UpB and $\mathrm{BC}$ also shows no systematic difference between them.) Moreover, there is no significant difference between coarsegrained and fine-grained firn. Of course, this does not mean that the different sites and firn types are identical, but only that any systematic difference is lost in the measurement and sampling errors. The magnitudes of such errors are discussed by Alley (1987b, unpublished); the scatter of points at a given density in Figures 8 and 9 provides a reasonable estimate of the random errors involved.

It remains possible that well-developed depth hoar in the upper $2 \mathrm{~m}$ differs in connectivity from other firn types. No fine-grained firn exhibits densities as low as the bestdeveloped depth hoar $\left(<200 \mathrm{~kg} \mathrm{~m}^{-3}\right)$, so comparison is not possible. Furthermore, technical difficulties in sectioning

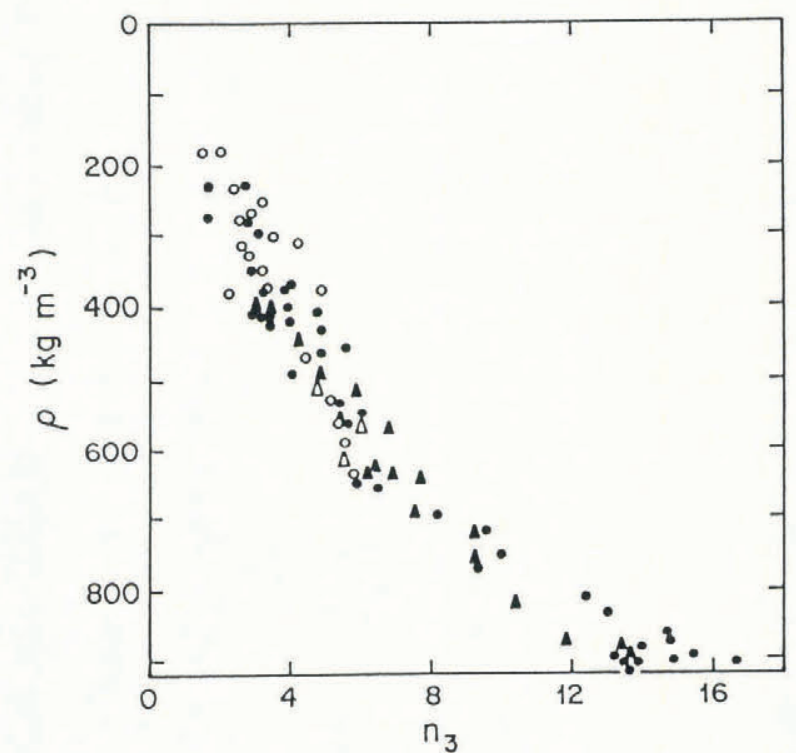

Fig. 9. Average number of bonds per grain $\left(n_{3}\right)$, plotted against density $(\rho)$. Symbols are the same as in Figure 8 .

well-developed depth hoar and in measuring its stereological parameters introduce greater uncertainty in the results. In deeper firn, rapid growth of depth-hoar grains by sublimation ceases and the grains become rounded to form coarse-grained firn which plots on the same densityconnectivity trends as fine-grained firn. Thus, within our measurement error, density is a good predictor of connectivity in all firn, except perhaps in well-developed near-surface depth hoar. Alley and others (1982) described differences in connectivity between samples of coarsegrained and fine-grained firn taken from layers at about the same depth at Dome C, East Antarctica; it is now clear that at least most of those differences can be ascribed to density differences.

\section{Grain-growth rates and textures}

Grain-growth data are shown in Figures 10 and 11 for $\mathrm{UpB}$ and BC. Grain-size is reported as $3 / 2$ the average

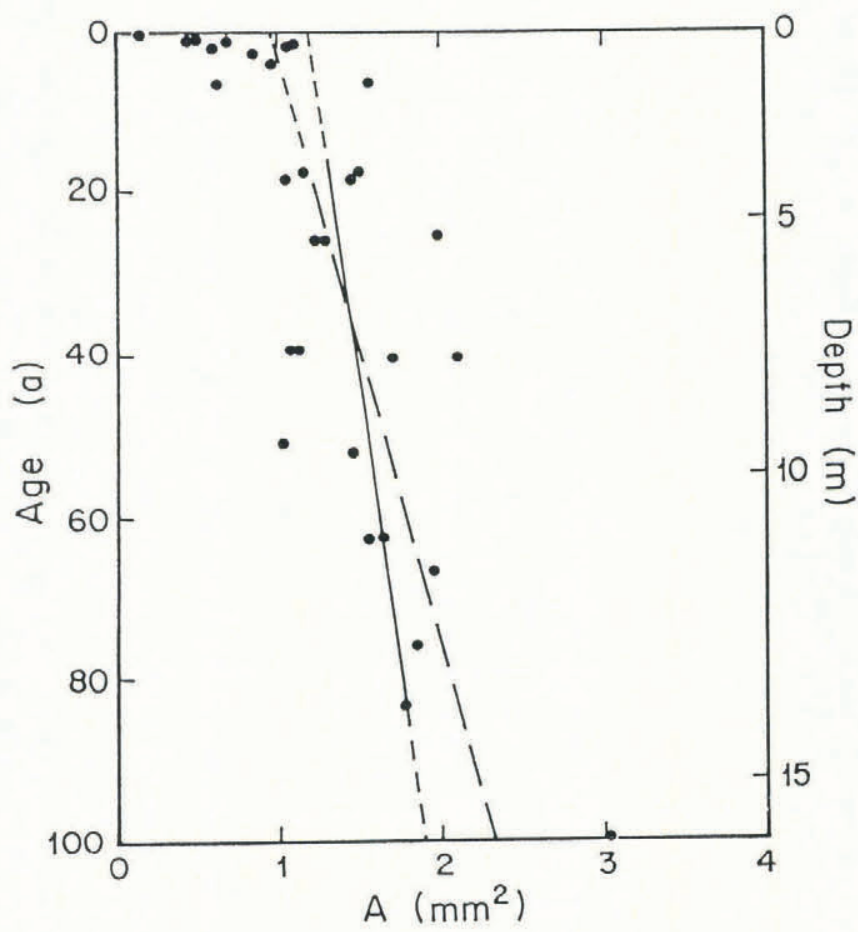

Fig. 10. Grain-size (A) plotted against age for UpB. Regression lines from 2 to $16 \mathrm{~m}$ (solid line) and from 2 to $17 \mathrm{~m}$ (long dashes) are shown. 


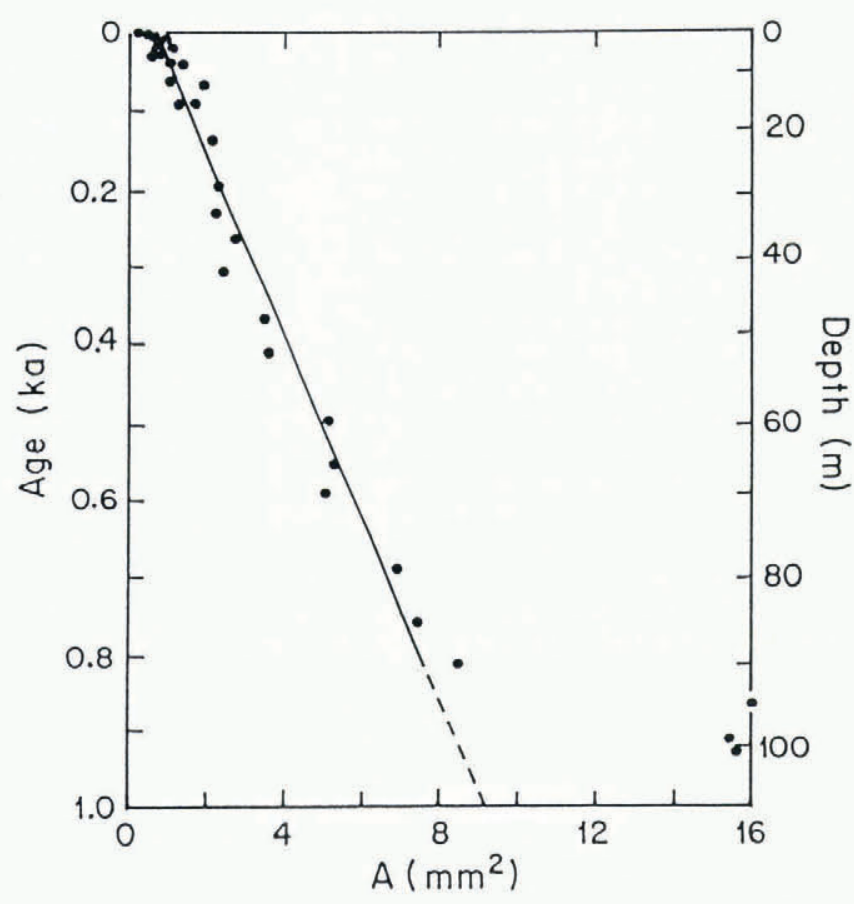

Fig. 11. Grain-size (A) plotted against age for BC. The regression line from 2 to $90 \mathrm{~m}$ is shown.

cross-sectional area of grains observed on a section plane; 100-200 grains were measured in most cases. Owing to technical difficulties, accurate grain-size data were obtained at $\mathrm{UpB}$ only down to $17 \mathrm{~m}$ depth. Because the data exhibit wide scatter, the grain-growth rate at UpB is not well determined. To show this, two regression lines of grainsize against age are plotted in Figure 10 . The regression line from 4 to $17 \mathrm{~m}$ gives a growth rate of $0.0136 \mathrm{~mm}^{2} \mathrm{a}^{-1}$, but elimination of the point at $17 \mathrm{~m}$ (which appeared unusually coarse-grained) reduces this to $0.0069 \mathrm{~mm}^{2} \mathrm{a}^{-1}$. For the temperature at UpB, Paterson (1981, p. 19) predicts a growth rate of about $0.009 \mathrm{~mm}^{2} \mathrm{a}^{-1}$. Data from the upper $2 \mathrm{~m}$ were omitted from the regression analysis because they show accelerated growth in response to temperature gradients and wind pumping (e.g. Gow 1969).

At UpB, pore close-off occurs at about $33 \mathrm{~m}$ depth. Even as shallow as $28-30 \mathrm{~m}$, horizontal thin sections reveal a preferred elongation of pores. Below this depth, grains begin to develop a shape elongation parallel to the bubble elongation, strain shadows appear, and the grain shapes become interpenetrative (that is, grains become branched and interlocking rather than convex and compact). Inspection shows that grain growth also accelerates below about $30 \mathrm{~m}$, although quantitative data are not available. A tracing of part of a typical horizontal section from $73.1 \mathrm{~m}$ is shown in Figure 12a; this should be compared with Figure 12c, which shows a normal, unstrained grain-growth texture from $109.1 \mathrm{~m}$ depth at Site A, Greenland, with equant grains and a relatively narrow grain-size distribution.

At Little America V, Gow (1970) reported development between about 50 and $150 \mathrm{~m}$ of textures similar to those we see at UpB, and proposed that these textural changes resulted from large horizontal stresses there. These textures develop between 30 and $70 \mathrm{~m}$ at $\mathrm{UpB}$, which may indicate that stresses at $\mathrm{UpB}$ are larger, or that the features at Little America $\mathrm{V}$ developed in a high-stress region up-stream and then were buried by accumulation in a lower-stress region closer to the drill site.

The grain-growth data from $\mathrm{BC}$ also show some complexity. The least-squares fit to data between 4 and $90 \mathrm{~m}$ (Fig. 11) gives a growth rate of $0.0085 \mathrm{~mm}^{2} \mathrm{a}^{-1}$, in good agreement with the expected value of about $0.009 \mathrm{~mm}^{2} \mathrm{a}^{-1}$ for the temperature at BC (Paterson 1981, p. 19). However, inspection of Figure 11 suggests that the grain-growth rate is not a constant but increases with age. This is especially true if the data from $95-100 \mathrm{~m}$ are included. The deeper data show a doubling of grain-size over only about $5 \mathrm{~m}$ (about 60 years) for a growth rate of about $0.14 \mathrm{~mm}^{2} \mathrm{a}^{-1}$ - a growth rate almost as large as that reported from highly strained ice at Little America V (Gow 1970).

Strain shadows, elongated, oriented bubbles, and other indicators of high stresses do not occur in the ice sampled at BC. However, whereas the upper part of the BC core exhibits a narrow grain-size distribution similar to that from Site A, the rapid grain growth below $90 \mathrm{~m}$ at $B C$ is accompanied by development of a bimodal texture, in which a few very large grains are surrounded by smaller grains (Fig. 12b). Such textures are observed during secondary recrystallization in metallurgy (e.g. Verhoeven 1975, pp. 354-356), when a few large grains grow at the expense of smaller, strained grains or at the expense of smaller grains for which grain growth has been stopped by microparticles or porosity. Perhaps the most likely explanation at $\mathrm{BC}$ is that the large grains are strain-free and have grown at the expense of smaller, strained grains, although strain has not been sufficiently rapid to cause bubble elongation or prominent strain shadows. The high
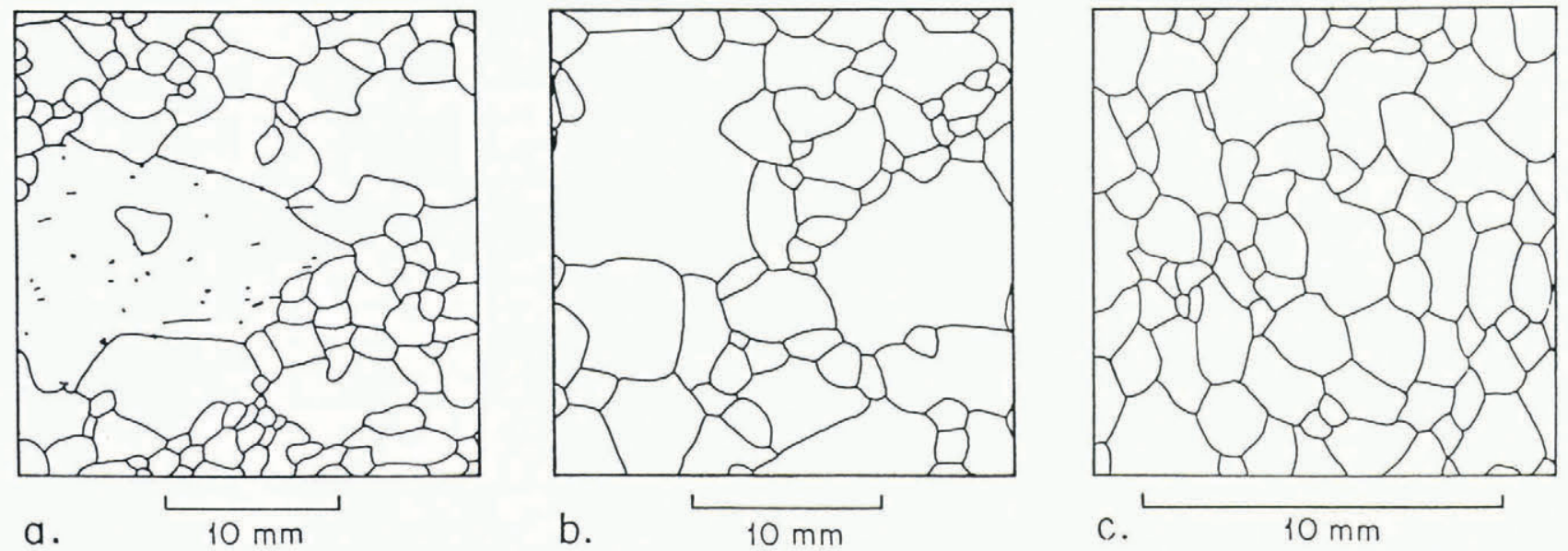

Fig. 12(a). Tracing of thin section from $73.1 \mathrm{~m}$ depth at UpB. The section was cut horizontally. Bubbles in the section and within or touching the large grain in the left-center of the figure are shown; all other bubbles are omitted.

(b). Tracing of thin section from $99.2 \mathrm{~m}$ depth at BC. The section was cut vertically, and the scale bar marks the bottom of the section. All pores have been omitted, but occupied about $2 \%$ of area.

(c). Tracing of thin section from $109.1 \mathrm{~m}$ depth at Site A, Greenland. The section was cut vertically, and the scale bar marks the bottom of the section. All pores have been omitted, but occupied about $3 \%$ of area. 


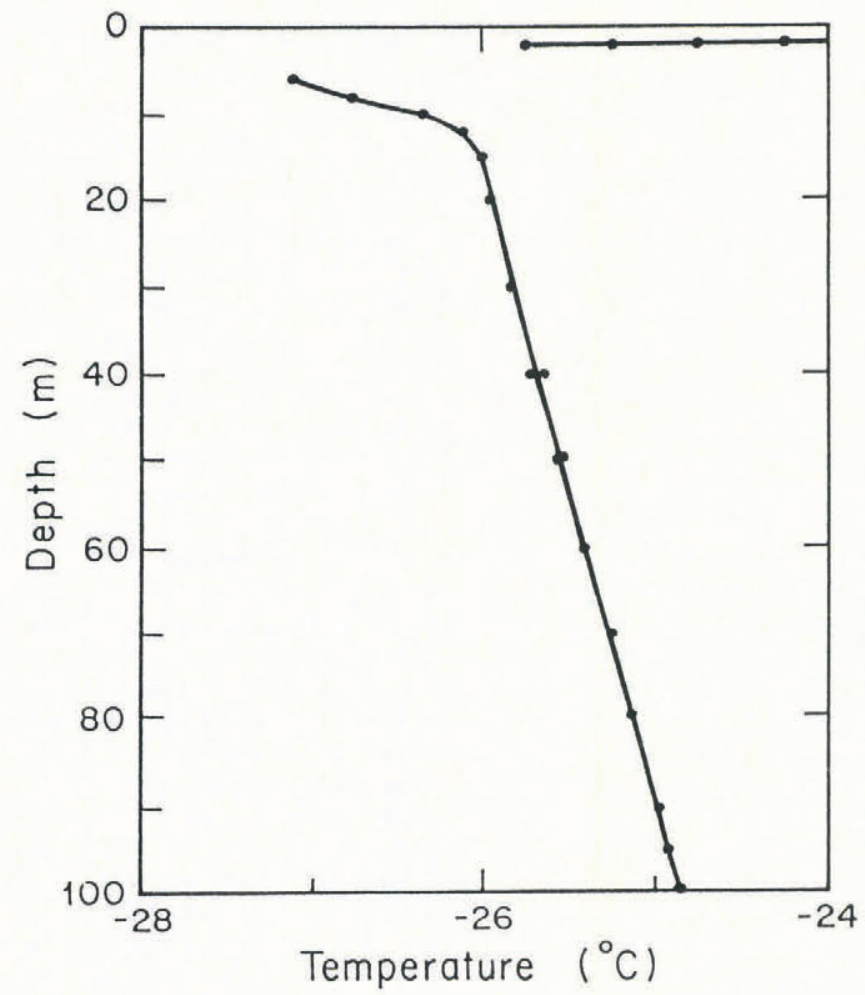

Fig. 13. Depth-temperature profile at BC. Points at 40 and $50 \mathrm{~m}$ were measured twice in order to assess scatter in the data.

temperature and low accumulation rate at BC may have contributed to the shallow depth at which this complex texture occurs.

\section{Temperature-depth profile}

The temperature-depth profile of Figure 13 was collected in the $\mathrm{BC}$ hole by B. Koci and W. Boller of the Polar Ice Coring Office (PICO), using the PICO temperature-logging system. The hole equilibrated for more than $24 \mathrm{~h}$ before logging; experience with the same drill and logging system in Greenland showed that this equilibration time was long enough to obtain temperatures within $\pm 0.1^{\circ} \mathrm{C}$ (personal communication from B. Koci, 1986).

The measured temperature gradient in ice from 20-100 $\mathrm{m}$ is high $\left(\approx 1^{\circ} \mathrm{C} / 75 \mathrm{~m}\right)$, indicating either a large steady heat flux, or strong non-steady effects such as a recent surface cooling or ice-sheet thinning. The nearby J9 core indicates relatively stable climate over the last 25003000 years (Grootes and Stuiver 1986), and melt events are more common in the last 500 years than in the previous 500 years (see below), so recent cooling seems unlikely. Longer-term changes in climate and thickness may be significant under certain circumstances, but cannot be estimated well because surface-temperature and ice-thickness histories are poorly constrained; oxygen-isotopic measurements now in progress on the core should provide useful data. From Ritz (1987), Waddington (1987), and our calculations it is likely that the heat flux at BC is within $10-20 \%$ of steady values.

Assuming that the heat flux is steady, a calculation following Robin (1955) from $80 \mathrm{~m}$ to the bed at $1000 \mathrm{~m}$ (Shabtaie and Bentley 1988, this volume), using the thermal parameters from Weller and Schwerdtfeger (1977) corrected to an average temperature of $-13^{\circ} \mathrm{C}$, gives a basal heat flux of $0.084 \mathrm{~W} \mathrm{~m}^{-2}$ (2.0 heat-flow units or HFU) and a basal temperature of $-1.3^{\circ} \mathrm{C}$. The pressure-melting point is about $-0.9^{\circ} \mathrm{C}$ (Hobbs 1974, p. 35 ); considering possible errors, the basal temperature is at or just below the melting point.

Internal deformation, the product of ice velocity and basal shear stress, accounts for about $0.004 \mathrm{~W} \mathrm{~m}^{-2}$ (0.1 HFU) (velocity $\approx 3 \mathrm{~m} \mathrm{a}^{-1}$ (Whillans and others 1987), shear stress $\approx 36 \mathrm{kPa}$ (Shabtaie and others 1987)), leaving a basal flux of about $0.080 \mathrm{~W} \mathrm{~m}^{-2}$ (1.9 HFU). Given the relatively constant ice thickness and surface slope over the short drainage basin leading to BC (Shabtaie and Bentley 1988, this volume), we consider it unlikely that the heat flux arises from basal freeze-on, suggesting that this basal flux is geothermal. By comparison, the geothermal flux at Byrd Station is about $0.071 \mathrm{~W} \mathrm{~m}^{-2}$ (1.7 HFU), if basal freeze-on is not occurring, from the measured basal flux of about $0.075 \mathrm{~W} \mathrm{~m}^{-2}(1.8$ HFU), corrected for a heat of sliding of $0-0.013 \mathrm{~W} \mathrm{~m}^{-2}$ $(0-0.3 \mathrm{HFU})$, with the lower end of the range being more likely. (Basal shear stress $\approx 50 \mathrm{kPa}$ and basal velocity $=$ $0-8 \mathrm{~m} \mathrm{a}^{-1}$, with the lower end more likely (Whillans 1977).) A high geothermal flux at BC is not surprising. The Siple Coast has been proposed as an area of active rifting (Davey 1981), and such regions typically have heat-flow values near $0.084 \mathrm{~W} \mathrm{~m}^{-2}$ (2 HFU; Lachenbruch and Sass 1978).

\section{Melt chronology}

Significant melt features in the UpB and BC cores are shown in Figure 14. If melt water percolated down in the

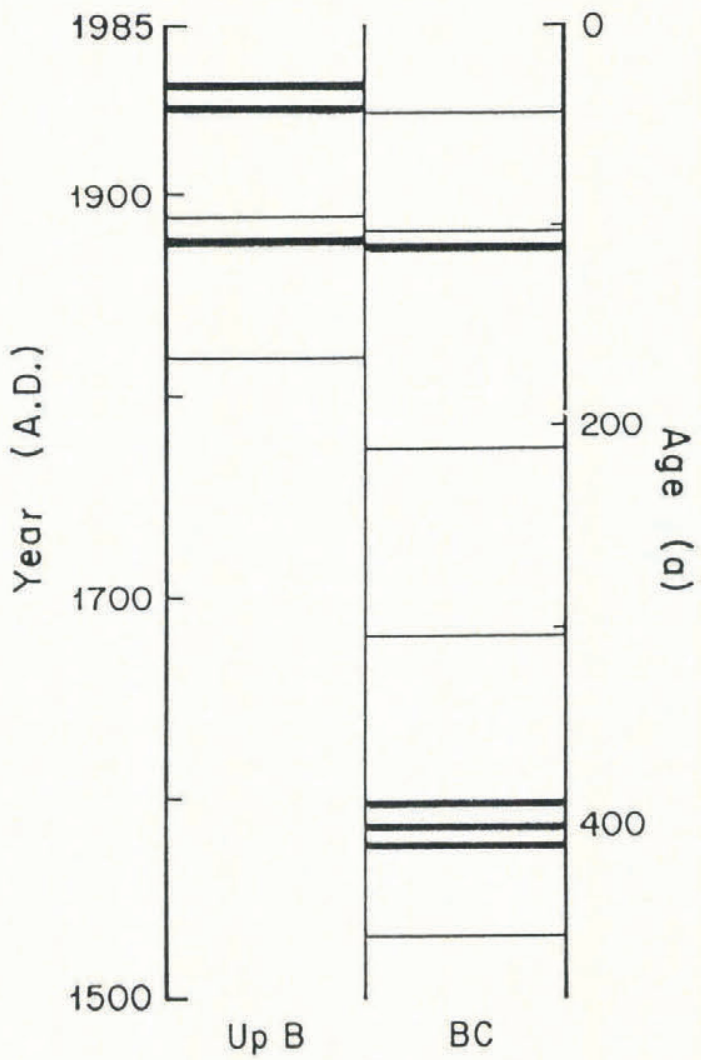

Fig. 14. Melt lenses in the UpB and BC cores. Only features that clearly represent melting (lenses, glands, and layers $>2 \mathrm{~mm}$ thick) are shown. Major events $(>20 \mathrm{~mm}$ thick) are shown by heavier lines.

firn before refreezing, then the ages of the melt events are slightly less than the ages of the surrounding firn or ice shown in Figure 14; percolation to a depth of $1 \mathrm{~m}$ would cause an error of about 5 years.

Over the last century, melt events seem to correlate well between the two cores. Melt events average about a 50 year spacing at BC back to A.D. 1530 (57 m), but no definite evidence of melt was observed in the 500 years before that. Although it is more difficult to recognize melt features in ice than in firn (especially given the somewhat variable core quality in the deeper ice), the lack of older melt features probably represents a real change in temperature, circulation patterns, or ice-sheet elevation. At $\mathrm{UpB}$, ice as recent as A.D. $1750(30 \mathrm{~m})$ originated at significantly higher elevation in the catchment, so the lack of older melt features at $\mathrm{UpB}$ may reflect conditions there. No melt features were observed in the Byrd Station core (except for melt lenses associated with volcanic ash) in the catchment area of Ice Stream D, although iced crusts $<2 \mathrm{~mm}$ thick were common (Gow 1968). 


\section{CONCLUSIONS}

Pit and core studies at UpB and BC on the Siple Coast of West Antarctica have yielded a number of interesting results. Accumulation rates are near $0.09 \mathrm{~m} \mathrm{a}^{-1}$ ice, and mean annual temperatures are near $-26.5^{\circ} \mathrm{C}$. Strata in firn record an annual signal, the low densities of depth hoar originate in the first year following deposition, and depth hoar densifies more rapidly than other types of firn. Density of firn is a good predictor of connectivity of grains for all firn types. Densification at $U p B$ is probably enhanced by strong longitudinal deviatoric stresses there. High stresses affect grain-growth rates and textures below about $30 \mathrm{~m}$ at $\mathrm{UpB}$, and the accumulated effects of stresses may explain anomalous textures and enhanced grain-growth rates below $95 \mathrm{~m}$ at $\mathrm{BC}$. Geothermal flux at $\mathrm{BC}$ is probably near 1.9 HFU. Melt events occur about once every 50 years, and correlate well between $\mathrm{UpB}$ and $\mathrm{BC}$.

Further studies are being conducted on the BC core, but melting during transport destroyed the usefulness of the UpB core. It is clear that more and deeper cores on ice streams and ridges will be required in order to provide further information on the history and behavior of ice on the Siple Coast.

\section{ACKNOWLEDGEMENTS}

We thank W. Boller, B. Koci, K. Kuivinen, and J. Litwak of the Polar Ice Coring Office, Lincoln, Nebraska, for field work, D. Susman for laboratory work, A.J. Gow for helpful comments, and A.N. Mares and S.H. Smith for manuscript and figure preparation. This research was funded by the U.S. National Science Foundation, Division of Polar Programs, under grants DPP83-15777 and DPP85-21038 to the University of Wisconsin Geophysical and Polar Research Center. This is contribution No. 481 of the Geophysical and Polar Research Center, University of Wisconsin-Madison.

\section{REFERENCES}

Alley, R.B. 1986. Three-dimensional coordination number from two-dimensional measurements: a new method. $J$. Glaciol., 32(112), 391-396.

Alley, R.B. 1987a. Firn densification by grain-boundary sliding: a first model. J. Phys. (Paris), 48, Colloq. Cl, Supplement au 3, 249-254.

Alley, R.B. 1987b. Texture of polar firn for remote sensing. Ann. Glaciol., 9, 1-4.

Alley, R.B. Unpublished. Transformations in polar firn. (Ph.D. thesis, University of Wisconsin-Madison, 1987.)

Alley, R.B. In press. Concerning the deposition and diagenesis of strata in polar firn. J. Glaciol., 34(118).

Alley, R.B., and B.R. Koci. 1988. Ice-core analysis at Site A, Greenland: preliminary results. Ann. Glaciol., $10,1-4$.

Alley, R.B., J.F. Bolzan, and I.M. Whillans. 1982. Polar firn densification and grain growth. Ann. Glaciol., 3, 7-11.

Crary, A.P., and C.R. Wilson. 1961. Formation of "blue" glacier ice by horizontal compressive forces. J. Glaciol., 3(30), 1045-1050.

Davey, F.J. 1981. Geophysical studies in the Ross Sea region. J. R. Soc. N.Z., 11(4), 465-479.

Fuchs, A. 1959. Some structural properties of Greenland snow. U.S. Army Snow, Ice and Permafrost Res. Establ. Res. Rep., 42.

Giovinetto, M.B. 1964. The drainage systems of Antarctica: accumulation. In Mellor, M., ed. Antarctic snow and ice studies. Washington, DC, American Geophysical Union, 127-155. (Antarct. Res. Ser., 2.)

Gow, A.J. 1965. Snow studies in Antarctica. CRREL Res. Rep., 177.

Gow, A.J. 1968. Deep core studies of the accumulation and densification of snow at Byrd Station and Little America V, Antarctica. CRREL Res. Rep., 197.
Gow, A.J. 1969. On the rates of growth of grains and crystals in south polar firn. J. Glaciol., 8(53), 241-252.

Gow, A.J. 1970. Deep core studies of the crystal structure and fabrics of Antarctic glacier ice. CRREL Res. Rep., 282.

Gow, A.J. 1975. Time-temperature dependence of sintering in perennial isothermal snowpacks. IASH Publ. 114 (Symposium of Grindelwald 1974 - Snow Mechanics), 25-41.

Gow, A.J., H.T. Ueda, and D.E. Garfield. 1968. Antarctic ice sheet: preliminary results of first core hole to bedrock. Science, 161(3845), 1011-1013.

Grootes, P.M., and M. Stuiver. 1986. Ross Ice Shelf oxygen isotopes and West Antarctic climate history. Quat. Res., 26(1), 49-67.

Hobbs, P.V. 1974. Ice physics. Oxford, Clarendon Press.

Lachenbruch, A.H., and J.H. Sass. 1978. Heat flow in the United States and the thermal regime of the crust. Washington, DC, American Geophysical Union, 626-675. (Geophys. Monogr., 20.)

Maeno, N., and T. Ebinuma. 1983. Pressure sintering of ice and its implication to the densification of snow at polar glaciers and ice sheets. J. Phys. Chem., 87(21), 4103-4110.

Paterson, W.S.B. 1981. The physics of glaciers. Second edition. Oxford, etc., Pergamon Press.

Ritz, C. 1987. Time dependent boundary conditions for calculation of temperature fields in ice sheets. IAHS Publ. 170 (Symposium at Vancouver 1987 - The Physical Basis of Ice Sheet Modelling), 207-216.

Robin, G. de Q. 1955. Ice movement and temperature distribution in glaciers and ice sheets. J. Glaciol., 2(18), 523-532.

Robin, G. de Q. 1983. General glaciology. In Robin, G. de Q., ed. The climatic record in polar ice sheets. Cambridge, etc., Cambridge University Press, 94-97.

Shabtaie, S., and C.R. Bentley. 1987. West Antarctic ice streams draining into the Ross Ice Shelf: configuration and mass balance. J. Geophys. Res., 92(B2), 13111336.

Shabtaie, S., and C.R. Bentley. 1988. Ice-thickness map of the West Antarctic ice streams by radar sounding. Ann. Glaciol., 11, 126-136.

Shabtaie, S., I.M. Whillans, and C.R. Bentley. 1987. The morphology of ice streams A, B, and C, West Antarctica, and their environs. J. Geophys. Res., 92(B9), 8865-8883.

Shimizu, H. 1964. Glaciological studies in West Antarctica, 1960-1962. In Mellor, M., ed. Antarctic snow and ice studies. Washington, DC, American Geophysical Union, 37-64. (Antarct. Res. Ser., 2.)

Verhoeven, J.D. 1975. Fundamentals of physical metallurgy. New York, John Wiley and Sons.

Vornberger, P.L., and I.M. Whillans. 1986. Surface features of Ice Stream B, Marie Byrd Land, West Antarctica. Ann. Glaciol., 8, 168-170.

Waddington, E.D. 1987. Geothermal heat flux beneath ice sheets. IAHS Publ. 170 (Symposium at Vancouver 1987 The Physical Basis of Ice Sheet Modelling), 217-226.

Weller, G., and P. Schwerdtfeger. 1977. Thermal properties and heat transfer processes of low-temperature snow. In Businger, J.A., ed. Meteorological studies at Plateau Station, Antarctica. Washington, DC, American Geophysical Union, 27-34. (Antarct. Res. Ser., 25.)

Whillans, I.M. 1977. The equation of continuity and its application to the ice sheet near "Byrd" Station, Antarctica. J. Glaciol., 18(80), 359-371.

Whillans, I.M., J. Bolzan, and S. Shabtaie. 1987. Velocity of ice streams B and C, Antarctica. J. Geophys. Res., 92(B9), 8895-8902.

Whillans, I.M., and R.A. Bindschadler. 1988. Mass balance of Ice Stream B, West Antarctica. Ann. Glaciol., 11, 187-193.

Zumberge, J.H., M.B. Giovinetto, R. Kehle, and J. Reid. 1960. Deformation of the Ross Ice Shelf near the Bay of Whales, Antarctica. I.G.Y. Glaciol. Rep. Ser., 3. 